\title{
The Degradation of Working-Class Status in Industrial France
}

\author{
Natalie Bradshaw \\ Ball State University
}

The first ripples of the Industrial Revolution were felt in France during the 1830s and 1840s. ${ }^{1}$ Although French industrialization occurred gradually over the nineteenth century, the commercialization of agriculture, adoption of powerdriven machinery, and utilization of mass production in factories that characterized it dramatically transformed the country's economy and ushered in new labor practices. $^{2}$ The economic expansion that accompanied this industrialization "increased the wealth of society as a whole," but often occurred "at the expense of the security and well-being of ordinary workers." ${ }^{3}$ While at the beginning of the nineteenth century, France valued artisans as the "backbone of the economy," the efficiency of mechanized production replaced the need for skill in many industries, allowing employers to hire unskilled employees that could be overworked and treated as disposable. ${ }^{4}$ As surviving memoirs from French workers reveal, unskilled workers were paid poorly, abused by their employers, could barely afford to feed themselves, resided in crowded, unsanitary conditions, and received minimal assistance from the government. French workers were made to feel like societal outsiders by wealthy bourgeoisie and unskilled workers began to see themselves as a distinctive social class. Tracing the evolution of the urban working-class experience in nineteenth-

\footnotetext{
${ }^{1}$ Jeremy Popkin, A History of Modern France (New York, NY: Routledge, 2016), 102.

${ }^{2}$ Mark Traugott, The French Worker: Autobiographies from the Early Industrial Era (Berkeley, CA: University of California Press, 1993), 10.

${ }^{3}$ Ibid., 6.

${ }^{4}$ Ibid., 11.
} 
century France through the history of industrialization and personal memoirs reveals how the shift from skilled to unskilled labor devalued workers' social status and ability to control their work environments, shaping their selfperceptions and generating feelings of class-consciousness.

In the preindustrial economy of the early nineteenth century, skilled artisans were major producers of French goods, often receiving assistance from extensive social networks. Trained for years by masters of their crafts, these artisans were taught how to create finished goods. Although the guild system was abolished during the French Revolution, traveling the country to diversify their talents and gain new techniques remained popular for many artisans-in-training. ${ }^{5}$ As illustrated in the memoir of Agricol Perdiguier, a joiner who was born in 1805 and traveled France for four years, journeymen on the Tour de France-the circuit of cities traveled by young artisans-received great support from their societies of fraternity brothers called compagnons. ${ }^{6}$ Members of these brotherhoods found work and lodging for each other, visited their sick in the hospital, and allowed promotion within their ranks. ${ }^{7}$ With this nationwide network of support, Perdiguier was never alone on his journeys and easily acquired employment.

Skilled artisans during this preindustrial time saw themselves as individual, socially mobile workers. Because they were well-trained in a specific

\footnotetext{
${ }^{5}$ Popkin, A History of Modern France, 48.

${ }^{6}$ Traugott, The French Worker, 116.

${ }^{7}$ Agricol Perdiguier, "Memoirs of a Compagnon," in The French Worker: Autobiographies from the Early Industrial Era, ed. Mark Traugott (Berkeley, CA: University of California Press, 1993), 117-182.
} 


\section{Bradshaw}

skill, artisans were valuable to employers. They had to be treated somewhat respectfully, and they did not have to tolerate abusive environments. In his memoir, Perdiguier writes of a confrontation that occurred between him and his employer, Mr. Gardot, where he is severely scolded by Mr. Gardot for a minor misunderstanding. Following the incident, Perdiguier is immediately able to square up his accounts and escape from his obstinate boss. ${ }^{8}$ This example illustrates that workers held the expectation that they would be treated justly. Skilled workers such as Perdiguier were highly sought after in workshops and supported by their brotherhoods; therefore, they did not have to agonize about leaving a job to search for another if they disliked their work environment. Furthermore, upon returning from their tours of France, these artisans expected to set up their own shops and sell their goods. ${ }^{9}$ There was little sense of workingclass consciousness among skilled artisans because, as they became shop owners, they saw themselves as self-sustaining workers and were able to advance socially to join the middle-class.

The class consciousness of workers began to emerge at the beginning of the century following the Revolution of 1830, when the bourgeoisie became a distinct social class. This development created a sharp fracture between wealthy industrialists who were elevated by the new regime called the July monarchy and poor urban workers who were not rewarded for their participation in the revolution. ${ }^{10}$ Also, during the 1830 s, the country "saw the first significant

\footnotetext{
${ }^{8}$ Perdiguier, "Memoirs of a Compagnon," 145-146.

${ }^{9}$ Perdiguier, "Memoirs of a Compagnon," 181.

${ }^{10}$ Popkin, A History of Modern France, 102.
} 
development of modern factory-based industry" and "the beginnings of profound social change that accompanied it." 11 As the use of mechanized production increased in northern French cities, industrialists "concentrated production processes in large factory buildings." ${ }^{12}$ In the close proximity of the factory floor, workers started to share ideas and see themselves as separate from the industrialists who owned the machinery and factories in which they labored.

The emergence of new production practices in the 1830s was met with growing discontent from the skilled artisans who lost their prestige in the face of mechanization and increasing numbers of unskilled, migrant workers that played a greater role in France's changing economy. Industrialization caused a surge of urban migration, as workers and former peasants traveled to northern cities in search of employment. Once in the cities, migrants faced terrible conditions. They were overworked and forced into crowded, unsanitary dwellings. ${ }^{13}$ Although laborers tried to retain their identity as individual workers, they felt dehumanized to the point that they considered themselves slaves in the bourgeois system of labor. The dramatic rhetoric of slave-like working conditions is found in documents from both the Revolution of 1848 and the Commune of $1871-$ revolts that were both initiated and fought by members of the working-class in hopes of more rights for industrial laborers. As revolutionary action failed to favorably reorganize labor and grant workers the rights they demanded, a

\footnotetext{
${ }^{11}$ Popkin, A History of Modern France, 102.

${ }^{12}$ Ibid., 103.

${ }^{13}$ Popkin, A History of Modern France, 109.
} 


\section{Bradshaw}

document from May 1871 lamented that "the worker continues to be enslaved by the employer, who holds absolute control over production." ${ }^{14}$ While workers joined together by forming mutual aid societies and consumer cooperatives and called for better conditions through newspapers, the failure of bourgeoisdominated regimes to address their grievances confirmed working-class beliefs that the economic system sought only to exploit them. ${ }^{15}$

In accordance with changes in production methods and working-class conditions, the memoirs of workers born after 1830 sharply contrast with the memoir of the skilled artisan Agricol Perdiguier. While some industrial workers were able to find support from mutual aid societies and cooperatives, the memoirs of Norbert Truquin, Jean-Baptiste Dumay, and Jeanne Bouvier bring to light "the occupational instability and marginality of those without skills, without knowledge, without the support of family or a circle of friends - in short, without resources of virtually any kind to help them in the struggle to survive." ${ }^{16}$ Unlike in Perdiguier's experience, there were no social safety nets for these three workers to rely on. They traveled and suffered through sickness alone, without the help of fraternities that could connect them with employers. Instead, they had to search, beg, and lie to secure employment. This job distress can be seen in the

\footnotetext{
14 "Report to the Citizen Delegate for Public Works on contracts for the supply of military uniforms" in The Communards of Paris, 1871, ed. Steward Edwards (Ithaca, NY: Cornell University Press, 1973), 130.

${ }^{15}$ Popkin, A History of Modern France, 110.

${ }^{16}$ Traugott, The French Worker, 250.
} 
case of Bouvier, a young woman who told employers she was eighteen years old, four years older than her actual age, to get hired. ${ }^{17}$

Because no national welfare system existed to aid workers, in times of true desperation, they had to rely on the charity of other laborers. When Truquin was in Compiègne, for example, he explains that a group of workers, "seeing that I was in such a pitiful state, my feet all bloody," put "straw in my wooden shoes and one of them even sacrificed half his undershirt to wrap my feet." ${ }^{\prime 18}$ Lacking assistance from the government and their employers, working-class citizens stepped up and helped each other. Through supporting fellow laborers-either by providing them with food, money, or lodging, or by helping them find employment - workers started to gain a sense of class consciousness as they recognized that others were suffering from the same types of injustice they experienced. What at first seemed simply to be charity from one worker to another came to resemble solidarity between members of the same social class. Help was extended to the hopeless, not only out of kindness, but out of workingclass duty to support fellow "slaves."

Moreover, unskilled laborers, deemed easily replaceable, had little control over their work environments. They did not always have the luxury of leaving a bad employer the way skilled laborers previously had because work was difficult to find, and they often did not have enough money to feed

\footnotetext{
${ }^{17}$ Jeanne Bouvier, "My Memoirs," in The French Worker: Autobiographies from the Early Industrial Era, ed. Mark Traugott (Berkeley, CA: University of California Press, 1993), 355.

${ }^{18}$ Norbert Truquin, "Memoirs and Adventures of a Proletarian in Times of Revolution," in The French Worker: Autobiographies from the Early Industrial Era, ed. Mark Traugott (Berkeley, CA: University of California Press, 1993), 268.
} 


\section{Bradshaw}

themselves as they searched for new opportunities. Also, the fear of being blacklisted, highlighted in the factory experience of Dumay, likely intimidated workers who would have otherwise stood up for their rights. ${ }^{19}$ Unlike artisans in the early years of the century, workers in the industrialized economy were devalued because they did not learn how to craft finished goods. They instead performed only a single part of the production process. This monotonous work was bemoaned by laborers who found the repetition physically and mentally harmful, and calls were made for the diversification of jobs. ${ }^{20}$ Without the ability to improve working conditions, social mobility became virtually impossible for the majority of urban laborers, who survived on their weekly payments.

Beginning in the new industrial world that emerged in the $1830 \mathrm{~s}$, the "rhetoric of the period...tended to describe urban society as being divided into two hostile blocs of bourgeois and proletarians" because the "laboring classes themselves were becoming more conscious of what divided them from the rest of society." 21 Many things divided laborers from other French citizens in a society ruled by the values and institutions of the bourgeoisie. Throughout the memoirs of the industrial laborers, wealthy bourgeoisie are painted as uncaring, with hypocritical attitudes about working-class conditions. The issue regarding working-class clothing provides an example that encapsulates these workers'

\footnotetext{
${ }^{19}$ Jean-Baptiste Dumay, "Memoirs of a Militant Worker from Le Creusot," in The French Worker: Autobiographies from the Early Industrial Era, ed. Mark Traugott (Berkeley, CA: University of California Press, 1993), 327.

20 "Address from the Central Committee on the Women's Union for the Defence of Paris and for the Aid to the Wounded to the Commission of Labour and Exchange," in The Communards of Paris, 1871, ed. Steward Edwards (Ithaca, NY: Cornell University Press, 1973), 135-136.

${ }^{21}$ Popkin, A History of Modern France, 110.
} 
perceptions of bourgeois attitudes. Truquin's and Bouvier's narratives include scenarios in which workers who can barely afford to feed themselves are criticized by the bourgeoisie for their shabby dress. Clothing was a major source of anxiety for workers, as they dreaded going out in public dressed in rags. In fact, Bouvier declares that as a child the only thing holding her back from drowning herself in the river was the fear that people would see her dirty apron when they laid out her corpse. ${ }^{22}$ Later, Bouvier was mocked by her employer for her lack of material possessions because she did not even have a trunk full of clothing. ${ }^{23}$ Truquin argued with a shop owner who scorned workers for not having clean clothes for Sundays. ${ }^{24}$

Clothing was also used as a barrier to make the lower classes feel like outsiders. Work clothes were not allowed in the museums and gardens of Paris, which implied that high-minded activities were only meant to be enjoyed by the upper-classes. ${ }^{25}$ The irony of the controversy surrounding clothing — not lost on the workers - was that the same class of people that were disparaging workers' appearances were the ones paying them minimal wages and monopolizing their time. These insults and exclusionary tactics deepened the rifts between the working-class and the bourgeois, instilling the perception in workers that they were an isolated group that the upper-classes misunderstood and abused.

The shifting self-perceptions and growing class consciousness of laborers demonstrate that the experience of the French working-class drastically

\footnotetext{
${ }^{22}$ Bouvier, "My Memoirs," 346.

${ }^{23}$ Ibid., 354.

${ }^{24}$ Truquin, "Memoirs and Adventures of a Proletarian in Times of Revolution," 293.

${ }^{25}$ Ibid., 283.
} 


\section{Bradshaw}

changed over the course of the nineteenth century. As mechanization replaced the need for skill and the effects of industrialism penetrated society, workers' status and quality of life were greatly reduced. Despite strong calls for reform and bloody revolutions that "increasingly strike historians as major milestones in modern French history," most working-class grievances were never fully addressed during the nineteenth century. ${ }^{26}$ It was not until the war-torn twentieth century that the aspirations of many laborers were realized. Most importantly, however, nineteenth century France saw the working-class emerge as its own social group with distinct objectives and values.

\footnotetext{
${ }^{26}$ Popkin, A History of Modern France, 93.
} 